\title{
Lives in a chiaroscuro. Should we suspend the puberty of children with gender identity disorder?
}

S Giordano

J. Med. Ethics 2008;34;580-584

doi:10.1136/jme.2007.021097

Updated information and services can be found at:

http://jme.bmj.com/cgi/content/full/34/8/580

These include:

Data supplement

"erratum"

http://jme.bmj.com/cgi/content/full/34/8/580/DC1

References This article cites 8 articles, 2 of which can be accessed free at:

http://jme.bmj.com/cgi/content/full/34/8/580\#BIBL

1 online articles that cite this article can be accessed at:

http://jme.bmj.com/cgi/content/full/34/8/580\#otherarticles

Rapid responses You can respond to this article at:

http://jme.bmj.com/cgi/eletter-submit/34/8/580

Email alerting Receive free email alerts when new articles cite this article - sign up in the box at service the top right corner of the article

Notes

To order reprints of this article go to:

http://journals.bmj.com/cgi/reprintform

To subscribe to Journal of Medical Ethics go to:

http://journals.bmj.com/subscriptions/ 


\title{
Lives in a chiaroscuro. Should we suspend the puberty of children with gender identity disorder?
}

\author{
S Giordano
}

Correspondence to:

Dr S Giordano, CSEP/IMLAB, and the Manchester Institute of Science, Ethics and Innovation, The University of Manchester, Williamson Building, The School of Law, Oxford Road, Manchester M13 9PL, UK; simona.giordano@manchester. ac.uk

Received 21 March 2007 Revised 21 December 2007 Accepted 9 January 2008

\section{ABSTRACT}

Transgender children who are not treated for their condition are at high risk of violence and suicide. As a matter of survival, many are willing to take whatever help is available, even if this is offered by illegal sources, and this often traps them into the juvenile criminal system and exposes them to various threats. Endocrinology offers a revolutionary instrument to help children/adolescents with gender identity disorder: suspension of puberty. Suspension of puberty raises many ethical issues, and experts dissent as to when treatment should be commenced and how children should be followed up. This paper argues that suspension of puberty is not only not unethical: if it is likely to improve the child's quality of life and even save his or her life, then it is indeed unethical to defer treatment.

A boy of 12 is believed to have become the world's youngest sex change patient after convincing doctors that he wanted to live the rest of his life as a female... The therapy involves artificially arresting male puberty, with a series of potent hormone injections... (Telegraph). ${ }^{1}$

In 2004 Alex, ${ }^{2}$ another trans-gender child, convinced the Australian Courts to allow her treatment for gender identity disorder. At the age of 13, her puberty was suspended. ${ }^{\mathrm{i}}$

Both these children suffer from Gender Identity Disorder (GID). This is a "condition in which individuals experience their 'gender identity' as being incongruent with their phenotype". "Their condition could also be described as a chiaroscuro, a term generally used in arts to describe figures painted in both light and shadow.

Children with GID can be treated with puberty suppressant drugs at the beginning of puberty or soon afterwards, when the first sex characteristics begin to appear. Physical development is thus arrested temporarily, in view of administering cross-sex hormones at a later stage (normally around the age of 16).

The main advantage of this approach is that these children gain time to reflect over their gender identity, without becoming trapped in a body that is experienced as alien.

While under puberty suppressant drugs, the child is assisted with psychotherapy and monitored medically, to verify any effects of medication, and may be encouraged to have what is called "a real life experience", that is, to dress and behave as a person of the other gender. This allows the child to

i Suspension of puberty can also be used for other conditions. In 2004 it was used in the "Ashley case". See http://www.telegraph.co.uk. explore the other gender and verify whether transition is what s/he really wants. ${ }^{4}$ After a period on puberty suppressant drugs, the child will decide whether s/he wants to go on with transition or not. Not all children with GID will become transsexual adults: some will change sex later in life, some might not, and some will continue to participate to both genders, feeling that their identity is not unequivocally male or female. If the child does not wish to transition, puberty suppressant drugs can be withheld and development restarts as normal. ${ }^{\text {ii }}$ If the child decides to change sex, transition is much smoother if puberty has been arrested. Starting cross-sex hormones on a body that has not developed the "wrong" sex characteristics allows achievement of a much more "normal" and satisfactory appearance. Every later cross-sex intervention on a person whose puberty has been allowed to progress is much more invasive: cross-sex hormones will act on a body that has already developed. The result is an ambiguous appearance. Some characters (height, size), once they have developed, cannot be reversed with hormonal therapy. Others (breasts, for example) can only be removed with surgery. Cross-sex surgery, for transgender people whose puberty has not been suppressed, is going to be much more invasive.

Suspending puberty can also be used as a part of diagnosis, as it helps to identify children who really want to transition ${ }^{4}$; it also decreases the risk of treating false positives (children who will seek cross-sex surgery once they are adult but who, later, will regret the choice).

Whereas suspension of puberty (SP) is regarded as a normal part of care in many countries, it can be very difficult to receive this treatment in England.

SP raises important ethical questions: can it be right to interfere with spontaneous development? Can children be capable of a judgment that can have long-term consequences? Is it ethical to offer this treatment, given that its risks have not been fully established within a research protocol?

I argue that SP should be offered when the longterm consequences of delaying treatment are likely to be worse than the likely long-term consequences of treatment. "Likely consequences" include longterm physical, psychological and relational/social results of treatment versus non-treatment, and thus the overall welfare of the child, and not just the potential risks and benefits of medications.

\footnotetext{
iidministration of hormones facilitate the restoration of puberty and return to the biological phenotype. ${ }^{4}$
} 


\section{PHYSICAL, PSYCHOLOGICAL AND SOCIAL DIMENSIONS OF GENDER IDENTITY DISORDER}

GID is a severe medical condition, associated with strong disgust for the body and profound uncertainty over the sense of the self. Invariably, growing in a chiaroscuro causes great distress. Once they start puberty, trans-boys may develop female secondary sex characteristics, such as breasts, may even start to menstruate and remain shorter in stature than average, whereas trans-girls may grow beards and prominent Adam's apples, experience erections and became taller than average.

Social adaptation can be very difficult. ${ }^{5}$ Children with GID typically wish to engage in plays that are distinctive of the other gender and identify themselves with the other gender. ${ }^{6}$ Once at school, they may feel uncomfortable in taking part in activities in which they are expected to share environments (changing rooms, dormitories) with their peers. Even going to the bathroom can become a major issue. For example, in Alex the school principal reported that Alex would wear nappies and refuse to drink for the whole duration of the school day, in order to avoid the bathroom. ${ }^{2}$

Moreover, the social response to GID is often one of rejection, discrimination and abuse. ${ }^{7}$ Homophobic bullying in schools is common in the UK $\mathrm{UK}^{8}: 89.2 \%$ of lesbian/gay/bisexual/transgender youth experience verbal bullying and $17.6 \%$ are physically assaulted for reasons related to their gender/sexual orientation. ${ }^{9}$ There have been cases of children killed by their peers by reason of their gender ambiguity. ${ }^{10}$

A 16-year-old male-to-female patient reports:

\begin{abstract}
Many [...] are ignorant and cruel and they shout out things like, "Girl with a cock", "There's the he/she/it", "Tranny boy" and other names. On my way to school, people shout similar comments from their cars, because of the way I look. [...] When I leave school, to go to University, or to get a job, I want to be able to keep my private life private; this is nobody else's business. (Personal communication, published with the kind permission of the patient and her parents).
\end{abstract}

This type of social response has negative long term consequences. Children who are victims of homophobic bullying are five times more likely than other students to fail to attend schools, and twice as likely not to pursue further education. ${ }^{11}$ Substance abuse, homelessness, prostitution, HIV infection, self-harm, depression, anxiety ${ }^{12}$ and suicide ${ }^{13}$ are also included among the results of homophobic bullying. ${ }^{14}$

\section{THE NEED FOR MEDICAL TREATMENT}

Given the severity of the condition, obtaining medical help is for many a matter of survival. If they are refused treatment, many might try to obtain medication off the illegal market. Injecting drugs at unregulated dosages and without medical supervision exposes them to dissatisfactory physical development and to life threatening conditions, such as HIV, AIDS and hepatitis. Involvement with illegal sources often also entangles these youth in the juvenile justice system, and "[once] a young person enters the juvenile justice system, the stigma of delinquency usually follows them throughout life and they often cycle into the adult criminal justice system upon maturity". ${ }^{15}$

Those who come from areas of the world where early treatment and change-sex surgery are unavailable need to emigrate in order to obtain proper medical care. Often they have to raise enough money for privately paid healthcare assistance, and given that sometimes clandestine immigration is the only way into countries where they can receive medical help, criminalised behaviour, such as prostitution, might become the only available option. ${ }^{16}$

It cannot be claimed that these people freely choose risky life styles: those who do not receive treatment are left without recourse, and "people without recourse are not free". ${ }^{17}$

Of course, many transsexual people do not have a similar fate, and are well integrated in society. However, research shows that delayed treatment is associated with poor outcome $e^{4}$ and ill physical, psychological and relational/social health (p121). ${ }^{5}$ Many would rather take their life than grow in the "alien" $\operatorname{body}(\mathrm{p} 3){ }^{12}$

It could be objected that we should not respond with biological treatment to a problem that is to an important extent social. If society responds in the wrong way to transgender children, we should not change their body, we should change society.

However, GID is not purely a social problem: it is a medical condition, whose causes seem to be genetic, hormonal and neuro-developmental. ${ }^{3}$ The appropriate response to a serious medical condition is medical treatment. Early treatment prevents these children from growing in an unwanted body, in a body that they would change anyway at a later stage, at much higher costs. Social education might be necessary, but this is a different matter.

\section{SUSPENSION OF PUBERTY: WHEN SHOULD IT START?}

The first stage of hormonal treatment for GID is the administration of puberty suppressant drugs. ${ }^{18}$

These drugs, sometimes called "blockers", by acting on the pituitary gland, block the hormone secretion ${ }^{\text {iii }}$ (oestrogen in girls and testosterone in boys). The most effective "blockers" are gonadotropin-releasing hormone analogues ( $\mathrm{GnRHa}$ ). After a period on "blockers", if the child persists in his/her desire to transition to the other gender, cross-sex hormones, and then surgery, will be offered.

The Harry Benjamin International Standards of Care ${ }^{19}$ recommend that these medications be given when the child has had some experience of his/her biological gender. ${ }^{\text {iv }}$

The reason for this is that only about a quarter of children with gender dysphoria under the age of 12 will become transsexual adults, ${ }^{18}$ whereas the majority of those who continue to experience transgenderism in adolescence become transsexual adults. ${ }^{20}$ Once puberty has been experienced, if the disorder is still strong and persistent, treatment can start. The stage at which the adolescent begins his puberty is known as Tanner Stage II and III. ${ }^{21}$ v At these stages, testes and breasts begin to grow and pubic hair begins to appear (for a fuller description see box 1). In many countries, such as Germany, the USA, Canada, Australia, The Netherlands and Belgium, SP can be offered at this stage of pubertal development. In England, instead, it could be very difficult to obtain treatment at this early stage.

\footnotetext{
iii These are sometimes called hypothalamic blockers. I am grateful to Mike Besser for clarifying the real nature of these hormone suppressant drugs. I owe the specifications contained in these lines to him.

iv The Royal College of Psychiatrists guidelines also recommend that adolescents have some "experience of themselves in the post-pubertal state of their biological sex", before any treatment commences, but contemplate the possibility that "for clinical reasons, it is [...] in the patient's interest to intervene before this [time]". ${ }^{18}$

${ }^{\mathrm{v}}$ It is possible to determine pubertal development accurately by measuring testicular and breast growth as well as the levels of circulating hormones. ${ }^{21}$
} 


\section{THE UK SITUATION}

In 2005, the British Society of Paediatric Endocrinology and Diabetes (BSPED) 22 stated that treatment for GID should not start until puberty is complete. This means that the child should be left to grow in the biological (unwanted) body. The effects of the puberty suppressant drugs are thus severely curtailed. It is in fact clear that puberty cannot be suppressed if it has completed its course. This exposes the child not only to the anguish and terror of growing in a body that is experienced as alien, and to the relational/social risks associated with this, but also to the ill effects of having to commence cross-sex treatment over a body that is already fully formed, and to much more invasive surgery, should $\mathrm{s} /$ he decide to transition.

The BSPED guidelines have now been withdrawn, but their publication brought to light a dissent about the appropriateness of SP and contributed to a climate of concern among professionals. The guidelines, published anonymously, were written by specialists in adolescent endocrinology at the University College of London Hospitals NHS Trust, which, in partnership with the Tavistock and Portman NHS Trust, provides the first and only Child and Adolescent GID Unit in the UK, one of the few units of this kind in the world. In practice, this means if a British resident was referred to the clinic, and the experts refused to treat him/her (based on application of the BSPED guidelines), it would have been extremely difficult for him/her to obtain another referral to a different service/specialist, and likewise difficult for other professionals in the UK to offer desired treatment, even if that treatment appeared to them to be in the patient's best interest $\mathrm{s}^{23}$ One result of this, is medical tourism: US specialists report having to treat several children who have been turned down at UK clinics. ${ }^{24}$ Those who cannot afford privately paid healthcare abroad are left in the UK to suffer.

What are the reasons against $\mathrm{SP} ?^{\mathrm{vi}}$

\section{UNKNOWN RISKS}

Hormone suppressant drugs are routinely administered to prostate cancer patients ${ }^{27}$ vii and to children who experience precocious puberty. These drugs are administered to children with GID in an experimental way. The long-term effects on bone mass development and sitting height, metabolism and on the brain, are not entirely clear. ${ }^{21}$ Additional concerns regard the effect of blockers on reproductive capability. ${ }^{25}$

It could be argued that experimenting on children/adolescents is irresponsible; that they cannot be competent to engage in experimental therapy; that it is impossible to give genuine consent to a therapy whose long-term risks are not entirely clear, and that therefore this form of therapy is necessarily unethical.

\section{A RESPONSE}

There is no ground for presuming that a child/adolescent with GID cannot be competent to make a judgment upon SP. ${ }^{25}$

Moreover, if it was impossible to give valid consent to treatment whose side-effects are unclear, it would follow that

\footnotetext{
${ }^{\mathrm{vi}}$ I do not discuss arguments that say that SP is wrong because it is a violation of nature, or arguments that appeal to God's plans and the sanctity of suffering. I have dismissed them elsewhere. ${ }^{25}$

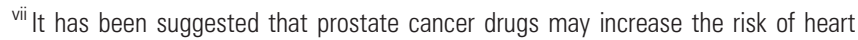
diseases. Experts in the field of paediatric endocrinology comment that similar risks cannot be found in the adolescent transgender population, for a number of reasons, one of which is that while testosterone is inhibited in this population, other hormones, like oestradiol, in males, are administered. ${ }^{27}$
}

no-one (including adults) could consent to medical research. This is obviously not true. In order to give valid consent, applicants need to receive honest information about known and potential risks and benefits of the treatment. In the balance, the applicant (often with the help of his/her parents) will weigh the known and potential risks and benefits of treatment with the known psychological and physical effects of non-treatment. There is no reason to regard consent thus obtained as invalid.

It is not necessarily unethical to treat children within an experimental monitored programme. Indeed, it might be unethical to deny what is for many the only possible cure.

If this cure was likely to cause significant harm to the child, it would be appropriate to question its legitimacy even in the face of the child's competence and informed consent, but research shows that SP appears to have no hideous or non-controllable side effects. ${ }^{4}$ After a period of $\mathrm{GnRHa}$ the child/adolescent might decide to revert to the biological sex, interrupt therapy and development is thought to restart as normal. For this reason, blockers are considered as "both temporary and reversible". ${ }^{28}$

However, Dr Russell Viner, one of the UK leading specialists in the field, stated that the claim that blockers are reversible is misleading. ${ }^{29}$

\section{VINER'S ARGUMENT ON REVERSIBILITY}

Viner argued that blockers have the irreversible outcome of denying the child the experience of puberty in the natural phenotype, and although puberty can be restored, it is irreversible that development has been interrupted at that particular point in time. Therefore, concludes Viner, blockers are not properly "reversible treatment".

This argument is "pseudo-philosophical argument". ${ }^{30}$ Aristotle would call it "an apparent deduction". ${ }^{11}$ Of course, when something has happened, nobody can undo reality. It does not follow that blockers are an irreversible treatment. It is irreversible that they have been given (or not given) but they are not for this reason irreversible medications. The adjective, in Viner's argument, is predicated of the wrong subject: irreversible is the fact that blockers have been administrated, but not blockers themselves. If Viner's argument was correct, even lipstick should be regarded as an irreversible intervention. If I wear lipstick today, in fact, I cannot make it un-happened. Instead, it is clear that, although it is "irreversible" that I have worn lipstick today, this does not make lipstick irreversible in the same way as cosmetic surgery, for example, is. To claim that lipsticks are irreversible interventions because, once I have worn them, it cannot happen that I have not worn them, is to display gross conceptual confusion between the ineluctability of the events (I have worn lipstick today) and the quality of things (lipstick is washable and does not become un-washable only because the past is ineluctable).

Moreover, with this argument Viner shoots himself in the foot: if Viner's argument was valid, it would follow that not suppressing puberty would equally be an irreversible intervention (any clinician who understood the implications of this conclusion would find it threatening). Viner's argument, thus, demonstrates the opposite of what it is meant to demonstrate: failing to treat is at least as irreversible as treating.

Maybe the sense of Viner's argument is different. Maybe he is suggesting that if we subvert endogenous hormone production, we might be unable to understand what the child really wants and the degree of his/her disorder. SP, in other words, might create confusion and impinge upon the clarity of the diagnosis. 


\section{Tanner stages ${ }^{26}$}

\section{Pubic hair (both male and female)}

Tanner I: no pubic hair at all (typically age 10 and under)

Tanner II: small amount of long, downy hair with slight pigmentation at the base of the penis and scrotum (males) or on the labia majora (females) (10-11)

Tanner III: hair becomes more coarse and curly, and begins to extend laterally (12-14)

Tanner IV: adult-like hair quality, extending across pubis but sparing medial thighs (13-15)

Tanner V: hair extends to medial surface of the thighs $(16+)$

Genitals (male)

Tanner I: prepubertal (testicular volume less than $1.5 \mathrm{ml}$; small penis of $3 \mathrm{~cm}$ or less)

Tanner II: testicular volume between 1.6 and $6 \mathrm{ml}$; skin on scrotum thins, reddens and enlarges; penis length unchanged

Tanner III: testicular volume between 6 and $12 \mathrm{ml}$; scrotum enlarges further; penis begins to lengthen to about $6 \mathrm{~cm}$

Tanner IV: testicular volume between 12 and $20 \mathrm{ml}$; scrotum enlarges further and darkens; penis increases in length to $10 \mathrm{~cm}$ and circumference

Tanner V: testicular volume greater than $20 \mathrm{ml}$; adult scrotum and penis of $15 \mathrm{~cm}$ in length

\section{Breasts (female)}

Tanner I: no glandular tissue; areola follows the skin contours of the chest (prepubertal)

Tanner II: breast bud forms, with small area of surrounding glandular tissue; areola begins to widen

Tanner III: breast begins to become more elevated, and extends beyond the borders of the areola, which continues to widen but remains in contour with surrounding breast

Tanner IV: increased breast size and elevation; areola and papilla form a secondary mound projecting from the contour of the surrounding breast

Tanner V: breast reaches final adult size; areola returns to contour of the surrounding breast, with a projecting central papilla.

Indeed, it can be difficult to make a correct diagnosis, and to determine the right time to commence treatment. This is, however, not a good reason to allow pubertal development in all cases, to the detriment of the child's welfare. Moreover, as SP combined with psychotherapy improves the precision of the diagnosis, it could prevent the risk of treating false positives. ${ }^{4}$

\section{CONCLUSIONS}

The following epitaph was published, with many more, by a non-profit charity in a website. It concerns a prostitute, murdered in Italy in 2003.

\footnotetext{
My name was Adrian Torres de Assuncao. I was a Brazilian woman aged 24. I lived in Brescia, in Italy. One night a client hit me in the face with a hammer. Despite the pain I kept working and I didn't go to hospital because I feared they would send me back home (I was a clandestine immigrant). When I agreed to go to hospital it was too late. I died on the $7^{\text {th }}$ of October.
}

This epitaph illustrates the fate of many of those who are left alone to deal with GID. Sufferers who are not helped in a timely manner, as a matter of survival, will take any chance to obtain the desired gender, even if this exposes them to serious risks, because anything is better than life in an alien body. In 2003, 38 similar murders have been reported across the world. Many of these victims were transgender adolescents or young adults, and it is well possible that, if early treatment was more largely available, many of them would still be alive.

If allowing puberty to progress appears likely to harm the child, puberty should be suspended. There is nothing unethical with interfering with spontaneous development, when spontaneous development causes great harm to the child. Indeed, it is unethical to let children suffer, when their suffering can be alleviated.

This is not responding with medicine to a problem that is social in nature. This is responding with medicine to a serious medical problem that causes enormous distress to the sufferers and makes them prefer unqualified help, street life and even death, to life with GID.

Whether or not the administration of puberty suppressant drugs is ethical depends not only on the net balance of clinical risks and benefits of treatment, but also on what is likely to happen to the child if $\mathrm{s} / \mathrm{he}$ is not treated at the early stages of puberty. On balance, healthcare providers should include future physical risks (invasiveness of future surgery), and the psychological and relational/social risks (disgust for the self; social integration; risk of suicide).

Healthcare providers are ethically (and to some extent legally) responsible for what is likely to happen to the applicant as a consequence of the fact that treatment has been withheld. ${ }^{32}$ Thus a decision on SP should involve a judgment on the overall quality of life and welfare of the child.

This implies that healthcare professionals should retain the freedom to assess their patients' condition, their competence and their best interests. No healthcare professional should find $\mathrm{him} /$ herself at risk of disciplinary action, if s/he acts in the patient's best interests and in line with established competent authorities, just because one professional body, however authoritative, considers SP clinically and ethically wrong, in stern and scarcely supported opposition to other well respected international authorities.

Acknowledgements: I wish to acknowledge A Alghrani, B Reed and T Reed, and $N$ Ferreira for offering comments on earlier drafts of this paper. Moreover, thanks to $\mathrm{R}$ Viner, C Brian and P Carmichael for engaging into debate with me. Special gratitude goes to M Besser, D Di Ceglie, P T Cohen-Kettenis, W Meyer, P De Sutter, N Spack, $\mathrm{P}$ Lee and $\mathrm{P}$ Clayton for offering clarification on endocrinological matters.

Competing interests: None.

\section{REFERENCES}

1. Pancevski B. Unhappy as a boy, Kim became youngest ever transsexual at 12 Telegraph, 2 Feb 2007. http://www.telegraph.co.uk/news/main.jhtml?xml =/news/ 2007/01/28/wkim28.xml (accessed 10 June 2008)

2. Re Alex [2004] FamCA 297.

3. GIRES. Atypical Gender Development-A Review. Int J Transgenderism 2006:9:29_ 44.

4. Cohen-Kettenis TP. Pubertal delay as an aid in diagnosis and treatment of a transsexual adolescent. Eur Child Adolesc Psychiatry 1998;7:246-8.

5. Cohen-Kettenis TP, Pfäfflin F. Transgenderism and intersexuality in childhood and adolescence. Making choices. London: Sage Publications, 2003.

6. Kotula D Jerry. In: Kotula D, Parker WE, eds. The Phallus Palace. Los Angeles: Alyson Publications, 2002:92-4

7. GIRES 2007. Transphobic Bullying in Schools. http://www.gires.org.uk/medpros.php (accessed 10 June 2008)

8. Warwick I, Chase E, Aggleton P. Homophobia, sexual orientation and schools: a review and implications for action. University of London, 2004, Research Report No 594. Available at www.dfes.gov.uk/research/data/uploadfiles/RR594.pdf laccessed 10 June 2008).

9. GLSEN's 2005. National school climate survey sheds new light on experiences of lesbian, gay, bisexual and transgender (LGBT) students, available online at http:// glsen.org/cgi-bin/iowa/all/library/record/1927.html (accessed 10 June 2008).

10. Di Ceglie D. Gender identity disorder in young people. Adv Psychiatr Treat 2000;6:458-66 
11. Hall Horace R. Teach to reach: addressing lesbian, gay, bisexual and transgender youth issues in the classroom. New Educator 2006;2:149-157:150.

12. Department of Health. Stand up for us: challenging homophobia in schools, 2007. Available at http://www.wiredforhealth.gov.uk/PDF/stand_up_for_us_04.pdf (accessed 10 June 2008).

13. Di Ceglie D, Freedman D, McPherson S, et al. Children and adolescents referred to a specialist gender identity development service: clinical features and demographic characteristics. Int J Transgenderism 2002;6. Online at http://www.symposion.com/ ijt/ijtvo06no01 01.htm (accessed 10 June 2008).

14. Whittle S, Turner L, Al-Alami M. Engendered penalties: transgender and transsexual people's experiences of inequality and discrimination. Equality Reviews 2007. Available at http://www.theequalitiesreview.org.uk/upload/assets/www. theequalitiesreview.org.uk/transgender.pdf (accessed 10 June 2008).

15. Fenner B, Mananzala R. Letter to the hormonal medication for adolescent guidelines drafting team. Oral presentation at the conference Endocrine treatment of atypical gender identity development in adolescents. London, 19-20 May 2005.

16. Fernanda de Albuquerque F, Janelli M. Princesa. Rome: Sensibili alle Foglie, 1994.

17. Korsgaard C. Capability and Well Being. In: Nussbaum M and Sen A, eds. The Quality of life. Oxford: Oxford University Press, 1999:59.

18. Royal College of Psychiatrists. Gender identity disorders in children and adolescents, guidance for management, Council Report CR63. January 1998. Online at http://www.symposion.com/ijt/ijtc0402.htm (accessed 10 June 2008).

19. Harry Benjamin International Gender Dysphoria Association's Standards of care for gender identity disorders. $6^{\text {th }}$ Version, February 2001. Online at www. hbigda.org/Documents2/socv6.pdf (accessed 10 June 2008).

20. Wren B. Early physical intervention for young people with atypical gender identity development. Clin Child Psychol Psychiatry 2000;5:220-31.
21. Delemarre-van de Waal $\mathbf{A H}$, Cohen-Kettenis TP. Clinical management of gender identity disorder in adolescents: a protocol on psychological and paediatric endocrinology aspects. Eur J Endocrinol 2006;155(suppl 1):131-7. online at: http://www.eje-online.org/cgi/content/full/155/suppl_1/S131\#F2 laccessed 10 June 2008).

22. British Society of Paediatric Endocrinology \& Diabetes. Guidelines for the management of Gender Identity Disorder (GID) in adolescents and children. specific endocrinological recommendations. Previously published at http://www.bsped.org.uk/ professional/guidelines/docs/BSPEDGIDguidelines.pdf:2. Currently removed from website.

23. See the case of Russell Reid. Guardian 25 May 2007. http://www.guardian.co.uk/ medicine/story/0,2088289,00.html www.guardian.co.uk/print/0,,329615991103701,00.html.

24. Personal communication

25. Giordano S. Gender Atypical Organisation in Children and Adolescents: Ethico-legal Issues and a Proposal for New Guidelines. International Journal of Children's Rights 2007; 15:365-90.

26. Tanner Stages. http://en.wikipedia.org/wiki/Tanner stage

27. Stein R. Prostate Cancer Drugs May Pose Danger. Washington Post 19 Sept 2006. http://www.washingtonpost.com/wp-dyn/content/article/2006/09/18/ AR2006091801167.html?nav = rss print/asection (accessed 10 June 2008)

28. Lee $\mathbf{P}$, Houk C. Diagnosis and care of transsexual children and adolescents: a pediatric endocrinologists' perspective. J Pediatr Endocrinol Metab 2006;19:103-9.

29. Dr R Viner oral presentation at the Royal Society of Medicine, 10 October 2006.

30. Platone. Rebubblica (Republic). Roma: Laterza, 2003, VI, 495a. My translation.

31. Aristotele. Topici (Topics). Napoli: Loffredo, 1974, VIII, 12, 162b 3-5. My translation.

32. Gillick v West Norfolk and Wisbech Area Health Authority [1985] 3 All ER 402 at $409 \mathrm{e}-\mathrm{h}$ per Lord Fraser.

\section{BMJ Masterclasses}

BMJ Masterclasses are educational meetings designed specifically to meet the learning needs of doctors. They help doctors keep up to date with the latest evidence and recent guidelines in major clinical areas, enabling them to use the latest evidence to make better decisions. The latest evidence, recent guidelines and best practice are delivered in an interactive and informative manner by leading experts. The speakers are specifically chosen as highly-skilled communicators who can authoritatively enthuse the audience and interpret the latest research and guidelines into practical tips for busy doctors. BMJ Masterclasses have proved a huge hit with clinicians, with many saying they have influenced their clinical practice.

http://masterclasses.bmj.com/ 